\title{
Unusual polygenetic void and cave development in dolomitized Miocene chalks on Barbados, West Indies
}

\author{
Jonathan B. Sumrall ${ }^{*}$, John E. Mylroie ${ }^{2}$, and Hans G. Machel ${ }^{3}$ \\ ${ }^{1}$ Department of Geography and Geology, Sam Houston State University, Huntsville, Texas, USA \\ ${ }^{2}$ Department of Geosciences, Mississippi State University, Mississippi State, Mississippi, USA \\ ${ }^{3}$ Department of Earth and Atmospheric Sciences, University of Alberta, Edmonton, Alberta, Canada
}

\begin{abstract}
Barbados provides an unusual case of polygenetic cave development within dolomitized chalks and marls of the Miocene Oceanics Group. These diagenetic processes are driven by a succession and interplay of tectonic uplift, fracturing, hypogene fluid injection, overprinting by mixing zone diagenesis, and mechanical and biological erosion in the current littoral zone. The significance of the voids and caves within the chalks on Barbados are: 1) these appear to be the first dissolution caves documented in dolomitized chalk, and 2) these features show a polygenetic origin documenting the diagenetic changes in lithology that allowed the development and preservation of these cave types.
\end{abstract}

Keywords: dolomitized chalk; polygenetic caves; Barbados; multi-stage dissolution

Received 7 May 2013; Revised 12 August 2013; Accepted 26 August 2013

Citation: Sumrall J.B., Mylroie J.E. and Machel H.G., 2013. Unusual polygenetic void and cave development in dolomitized Miocene chalks on Barbados, West Indies. International Journal of Speleology, 42 (3) 247-255. Tampa, FL (USA) ISSN 0392-6672 http://dx.doi.org/10.5038/1827-806X.42.3.8

\section{INTRODUCTION}

Globally, dolomitized chalks are rare and relatively small in extent; however dolomitization in what is typically an impermeable unit is important when considering their diagenetic and hydrologic history. Wolfe (1970) reported dolomite locally in the Senonian chalks of Northern Ireland, derived from modified seawater. Joergensen (1983) reported dolomite cements in chalks from the North Sea Central Graben. Dolomitization of Late Cretaceous chalk in the southeastern Paris Basin was attributed to seawater entering the chalk as groundwater in structural depression areas (Thiry et al., 2003). On Barbados, dolomite in the Miocene chalk is fine-crystalline and replacive, attributed to replacement by methane-bearing fluids in cold seep environments (Machel et al., 2012).

Caves in chalk are relatively rare. Several chalk caves are found in the English chalk (Bradshaw et al., 1991). In France and Belgium large chalk caves are more common, and caves over a kilometre in length have been explored (Waltham, 1975; Rodet, 1985). Small conduits (50-300 $\mathrm{mm}$ in diameter) have been reported in cliff exposures and quarry faces in England (Maurice et al., 2006). However, there are apparently no reported caves currently known in dolomitized chalks.

\section{Barbados}

Barbados is an uplifted carbonate island located on a forearc bulge, formed on the crest of an accretionary prism, about $125 \mathrm{~km}$ east of the Lesser Antilles volcanic island arc. The island is approximately 23 x $32 \mathrm{~km}$, with $432 \mathrm{~km}^{2}$ of area (Fig. 1). Glacioeustasy and episodic tectonic uplift have created a series of limestone terraces fronted by cliffs (e.g. Humphrey, 1997). The island conforms to the Carbonate Island Karst Model (CIKM) classification of a composite island (Mylroie \& Mylroie, 2007).

The strata of the island from oldest are: 1) Eocene, tectonically deformed deep-sea clastics of the Scotland Formation; 2) flat-lying Miocene chalks and marls of the Oceanics Group; and 3) a series of Pleistocene carbonate terraces that are pervasively karstified (e.g., Speed, 1990; Taylor \& Mann, 1991; Machel, 1999; Jones \& Banner 2003). The clastics are exposed in the Scotland District (Fig. 1), and stream caves have developed in the Upper Coral Reef Terrace. The most conspicuous surface and near-surface post-depositional attributes of the Pleistocene carbonates are karst features, which include several dozen deeply incised gullies (dry valleys), abundant sinkholes, and caves of various sizes and origin (Day, 1983; Machel, 1999, 2011; Machel et al., 2012).

\section{Geological framework}

The 'basement' of Barbados is a structurally complex accretionary prism complex composed of terrigenous turbidites and gravity-flow deposits interbedded with hemipelagic and pelagic radiolarites of Eocene age (Speed, 1990). The Scotland Sandstone, which is part of 


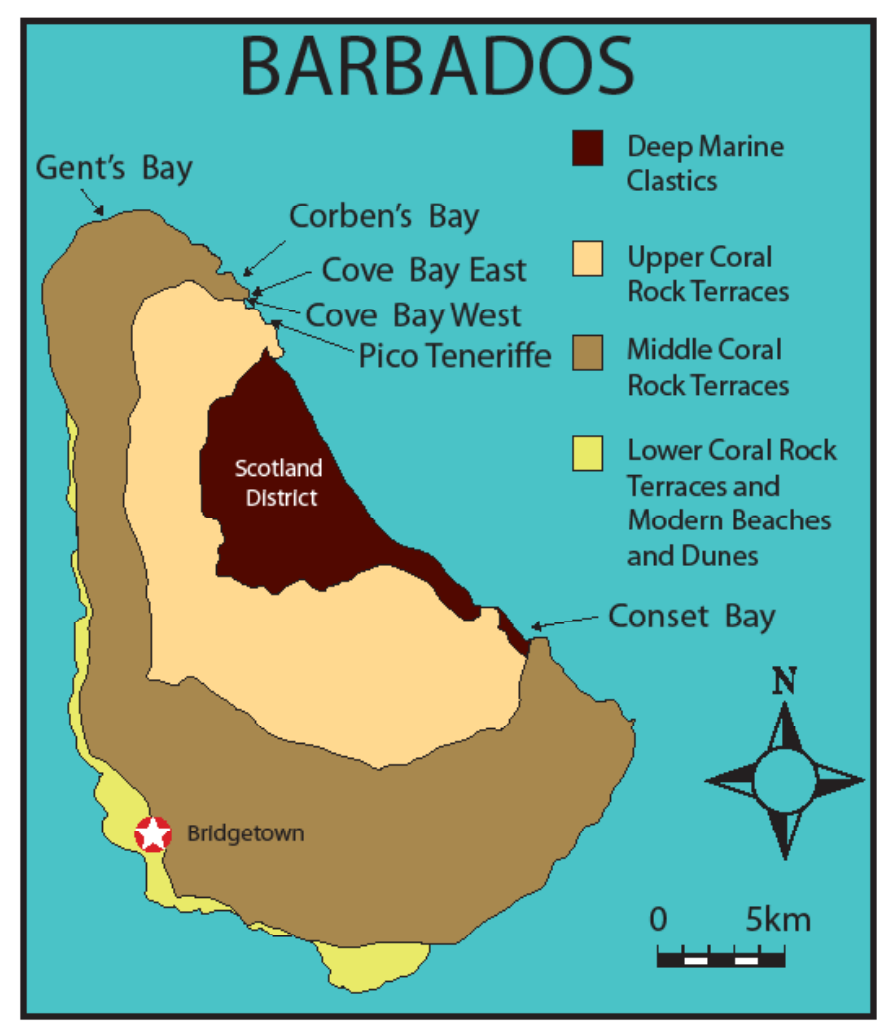

Fig. 1. Simplified geologic map of Barbados showing sampling sites (modified from Machel, 1999). Chalks of the Oceanics Group are not resolvable at this scale. They are found as localized outcrops or as parts of cliffs capped by Pleistocene limestones.

this sequence, hosts hydrocarbons that sustain a small local oil industry. The largest oil field is in the southern part of the island, where dozens of small fault-bounded traps have been drilled to depths of about 1,000-2,000 $\mathrm{m}$. Oil and gas extrude in a number of natural seeps, one of which at Conset Bay (Fig. 2) has been known for more than 200 years and from which bitumen was taken for domestic and medicinal purposes (Schombourgh, 1848). Solidified bitumen (locally known as manjak) was mined in the early part of the $20^{\text {th }}$ century (Senn, 1944; Parnell et al., 1994). There also was a well-known natural gas seep in the Scotland District called 'Boiling Spring', now covered and no longer active, where flammable gas bubbled up and burned for years (Schombourgh, 1848).

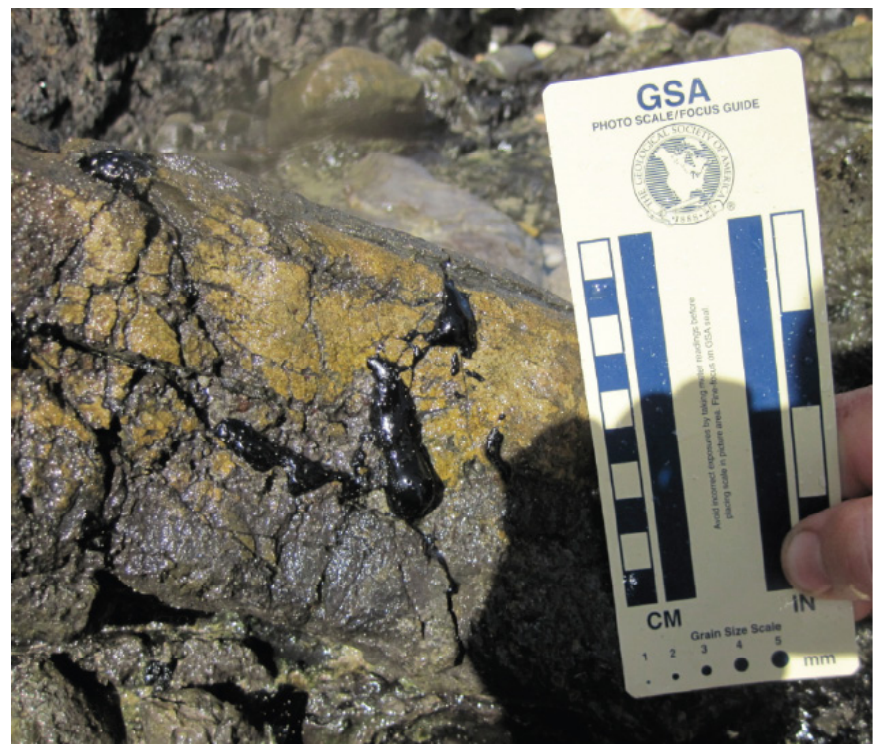

Fig. 2. One of the most prominent oil seeps at Conset Bay. Oil can be seen seeping from joints within the chalk (photo by J. Mylroie).
Tectonic diapirs consisting of a mélange of organic mud matrix intrude the pelagics of the Scotland District units. Emplacement of these diapirs likely continues today and is possibly responsible for the elevation of Barbados above the rest of the accretionary prism (Speed, 1990). Throughout most of the Neogene, Barbados has experienced tectonic uplift at rates averaging approximately 0.3 to $0.4 \mathrm{~m} \mathrm{ky}^{-1}$ (Speed, 1990).

A layer of Miocene chalks and marls, up to $50 \mathrm{~m}$ thick, called the Oceanics Group, overlies the deformed clastics of the Scotland Formation (Senn, 1946). The presence of natural oil seeps indicates that the chalks are likely breached by fractures, or missing as a local confining unit in a few locations.

The Oceanics Group is overlain by a series of Pleistocene carbonate terraces fronted by cliffs. These cliffs were formed by the interplay of glacioeustasy, episodic tectonic uplift, and erosion. The three major terraces, which consist of multiple smaller-scale terraces and sedimentary parasequences, are the Upper Coral Rock terrace, Middle Coral Rock terrace, and Lower Coral Rock terrace (Fig. 1). The ages of these terraces are approximately 800-500 ka, 490-250 ka, and 120-60 ka, respectively (Humphrey, 1997; Machel, 1999, 2011; Schellmann \& Radtke, 2004), and they cover about $85 \%$ of the island. Additional information about the geotectonic and sedimentary evolution of the island can be found in Jukes-Browne \& Harrison (1891), Speed (1983, 1990, 2002), Torrini et al. (1985), Humphrey (1997), Machel (1999, 2011), Schellmann \& Radtke (2004); and Machel et al. (2012).

\section{Karst}

Broadly, karstification and karst features fall into two genetic groups: epigene (also called epigenetic or epigenic), whereby dissolution is coupled to surface water hydrology; and hypogene (also called hypogenetic or hypogenic), whereby dissolution is decoupled from surface hydrological processes, and dissolutional aggressivity is developed at depth (Palmer, 2000; Klimchouk, 2007). According to Palmer (2000), carbonate hypogene caves are the product of dissolution in water in which the aggressiveness has been produced at depth beneath the surface, independent of surface or soil $\mathrm{CO}_{2}$ or other nearsurface acid sources. In addition to the geochemical definition above, there is another approach at defining hypogene speleogenesis, based on the hydrogeologic setting. This hydrogeological approach defines hypogene speleogenesis as the formation of solutionenlarged permeability structures by water that recharges the cavernous zone from below, independent of recharge from the overlying or immediately adjacent surface (Ford, 2006; Klimchouk, 2007, 2013). Flank margin caves are a unique subset of coastal caves considered hypogene by the geochemical approach (Mylroie \& Mylroie, 2007; Palmer 2007), but not by the hydrogeologic approach. Flank margin caves form at the flank of an enclosing landmass in the distal margin of a freshwater lens by the mixing of saline and fresh waters. Flank margin caves were originally described from eogenetic rocks in the Bahamas; however, the terms have been expanded to other coastal and diagenetic settings globally (Mylroie \& Mylroie, 2007). 


\section{Objectives}

The objectives of this study are documentation of the unusual caves developed within a relatively rare geologic occurrence of dolomitized chalk on Barbados and the development of a genetic mechanism for the caves.

\section{METHODS}

Fieldwork for this study was conducted in December 2009 and December 2011. A total of thirty-three rock samples were taken from the Miocene chalk at Cove Bay, Gent's Bay, Pico Teneriffe, Conset Bay, and Corben's Bay (Fig. 1). Bulk samples, ranging from a few grams to about $1 \mathrm{~kg}$ in mass, were collected for petrographic and geochemical analyses from outcrops preferentially along joint and fracture planes, and from the walls of voids.

Samples were powdered in the laboratory for X-ray diffraction (XRD) and geochemical analyses using a low speed dental drill assembly. Powder XRD patterns were obtained using a Rigaku Ultima IV diffractometer. X-ray diffraction patterns were obtained as follows: continuous mode, $0.02^{\circ} 2 \theta$ per step, $4^{\circ} 2 \theta$ per minute, $3-70^{\circ} 2 \theta$, $\mathrm{CuKa}$ radiation. Mineral percentages were estimated from relative intensities of peak heights of X-ray diffraction lines using JADE 9. Quartz powder was added to powder mixtures as a standard due to its lack of interfering peaks with calcite and dolomite. Duplicate analyses indicate a reproducibility of $\pm 5 \%$ of relative calcite/dolomite mixtures. Standard thin sections of $30 \mu \mathrm{m}$ were used for petrographic analysis with the assistance of staining by Alizarin Red-S for identification of carbonate species.

Carbon and oxygen isotope analyses were performed according to standard procedure (McCrea, 1950) at the University of Calgary. The results were reproducible within $\pm 0.1 \%$ or for $\delta^{18} \mathrm{O}$ and $\delta^{13} \mathrm{C}$. The dolomite $\delta^{18} \mathrm{O}$ values were corrected by the $-0.82 \%$ phosphoric acid fractionation (Scharma \& Clayton, 1965). Samples of mixed calcite-dolomite mineralogy were separated by standard differential acid digestion (1-3 hours for calcite, 2-4 days for dolomite; Schrama \& Clayton, 1965).

The caves were mapped using a tape or Disto ${ }^{\circledR}$ laser rangefinder and Suunto ${ }^{\circledR}$ compass. Field sketches were scanned and rectified using the cave mapping software Compass ${ }^{\circledR}$. Cave dimensions were measured from the resulting map using the NIH freeware Image J.

\section{RESULTS}

Outcrops of the chalks and marls of the Oceanics Group were investigated on Barbados. An outcrop at Cove Bay was the focus of the majority of this study (Figs. 1 and 3). Cove Bay is a crescent-shaped embayment on an otherwise relatively straight eastern coastline, opening into the Atlantic Ocean. The north face of the bay exposes chalk over a distance of more than $100 \mathrm{~m}$. This outcrop has been divided into east and west sections based on the presence of a rocky spur in the western portion.

In thin section, samples of the chalk are typical mudstones with abundant microfossils (Fig. 4A). Narrow fractures are present, typically lined with microsparitic dolomite cement, sometimes containing residual dead oil (Fig. 4B). The mineralogy calculated from X-ray diffraction is presented in Table 1 . The two main minerals detected in the chalks of the Oceanics Group were calcite and dolomite. Calcite was the dominate carbonate mineral in most outcrops of the chalk; however, the outcrop at Cove Bay West contained significantly higher dolomite percentages. No other minerals were detected. Dolomitized chalks were typically harder and more resistant to weathering. Chalk outcrops also contained a series of caves large enough to be mapped and other smaller voids that were photodocumented (Figs. 5 and 6).

The $813 \mathrm{C}$ values of dolomite from all locations vary from +4.9 to $-23.0 \%$ o PDB and for calcite vary from +7.3 to $-22.6 \%$ PDB (Table 2 and Fig. 7).. See Table 2 for isotopic values of all samples.

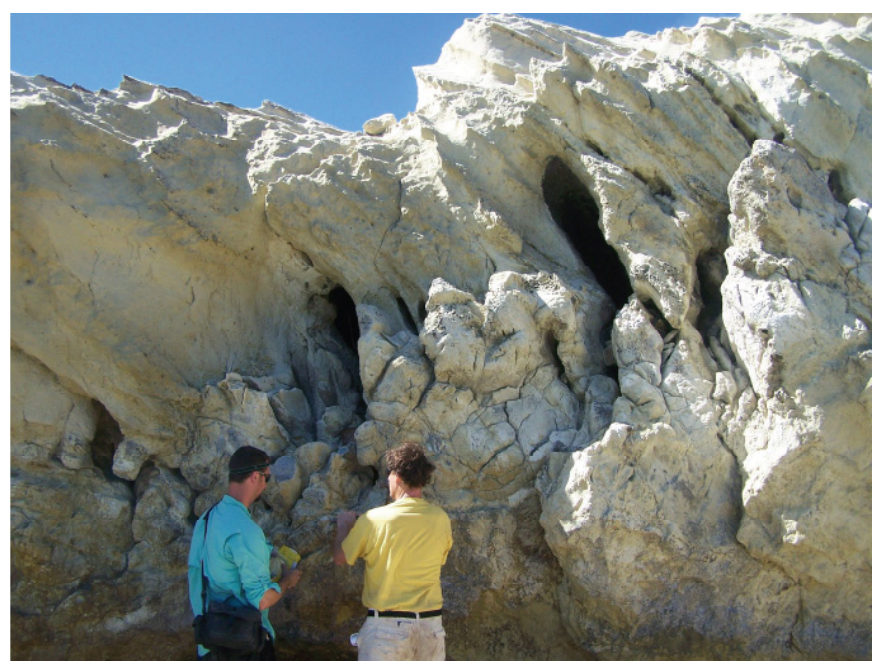

Fig. 3. Outcrop view of Cove Bay West and dissolutional voids.

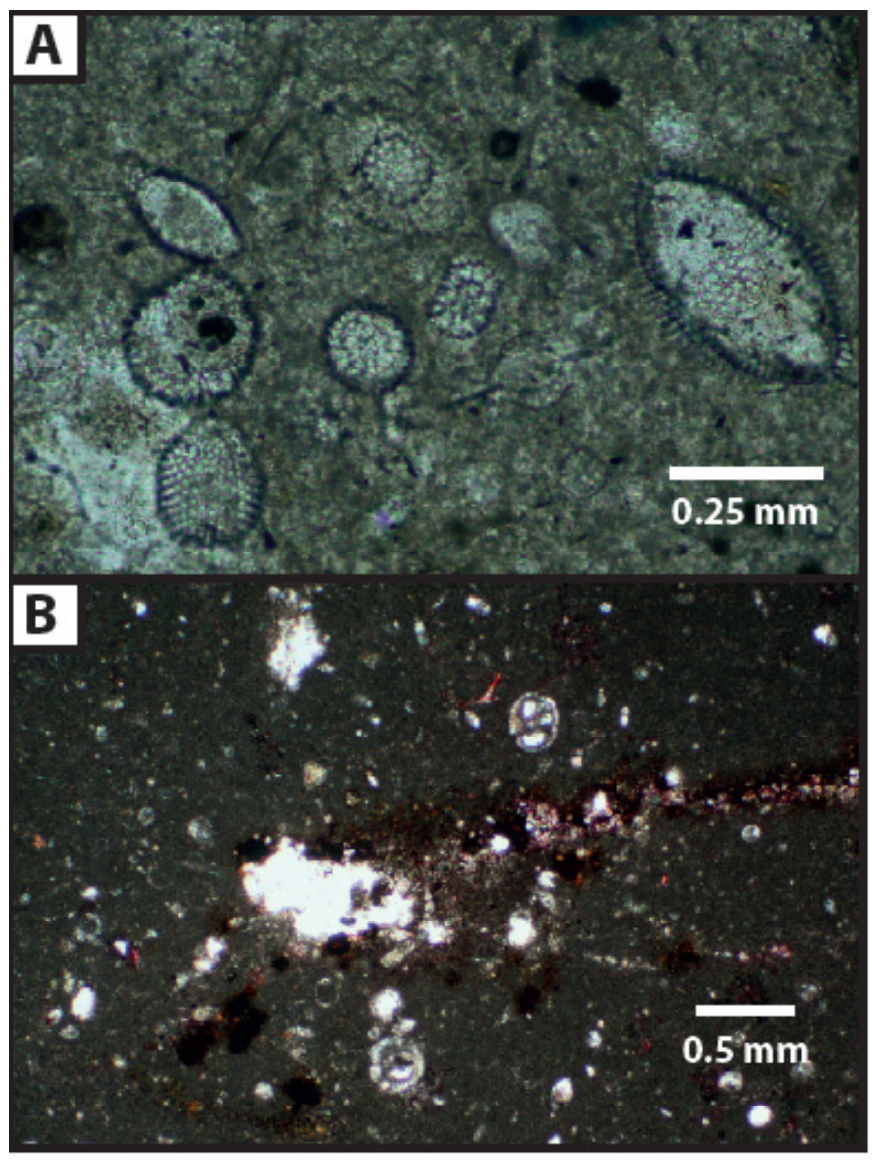

Fig. 4. A) Thin section photomicrograph of limestone chalk from Cove Bay East; B) Thin section photomicrograph of chalk from Cove Bay West. The matrix is dolomitized, which is indicated by staining and also revealed by $X R D$. Note narrow crack across the center of the image, partially lined with dead oil, which also occurs as a few blotches in the matrix nearby. 
detected in the chalks of the Oceanics Group were calcite and dolomite. Calcite was the dominate carbonate mineral in most outcrops of the chalk; however, the outcrop at Cove Bay West contained significantly higher dolomite percentages. No other minerals were detected. Dolomitized chalks were typically harder and more resistant to weathering. Chalk outcrops also contained a series of caves large enough to be mapped and other smaller voids that were photodocumented (Figs. 5 and 6).

The $\delta^{13} \mathrm{C}$ values of dolomite from all locations vary from +4.9 to $-23.0 \%$ PDB and for calcite vary from +7.3 to $-22.6 \%$ PDB (Table 2 and Fig. 7).. See Table 2 for isotopic values of all samples.

As previously mentioned, the chalks with higher dolomite concentrations were hard, and these outcrops of chalk contained abundant fractures (Fig. 8). As indicated by the presence of hydrocarbon seeps, hydrocarbons have exploited and migrated up these fractures (Fig. 2). Fractures are further coincident with caves, and these caves are aligned along a horizontal datum (Fig. 3).

Table 1. Table of relative dolomite percentages from Barbados samples.

\begin{tabular}{|l|c|l|}
\hline Sample: & Dolomite $\%$ & \multicolumn{1}{|c|}{ Location } \\
\hline A5 DOL & 100 & Cove Bay(NW) \\
\hline A6 DOL & 100 & Cove Bay(NW) \\
\hline A7 DOL & 75 & Cove Bay(NW) \\
\hline A8B DOL & 50 & Cove Bay(NW) \\
\hline A8C DOL & 40 & Cove Bay(NW) \\
\hline A8D DOL & 60 & Cove Bay(NW) \\
\hline A9 DOL & 50 & Cove Bay(NW) \\
\hline Z1 DOL & 20 & Cove Bay(NW) \\
\hline Z1A DOL & 40 & Cove Bay(NW) \\
\hline Z2 DOL & 95 & Cove Bay(NW) \\
\hline Z7A DOL & 30 & Cove Bay(NW) \\
\hline Z8A DOL & 10 & Cove Bay(NW) \\
\hline C1 DOL & $<5 \%$ & Cove Bay (NE) \\
\hline C10 DOL & 15 & Cove Bay (NE) \\
\hline C11 DOL & $<5 \%$ & Cove Bay (NE) \\
\hline C12 DOL & $<5 \%$ & Cove Bay (NE) \\
\hline C13 DOL & $<5 \%$ & Cove Bay (NE) \\
\hline C2 DOL & $<5 \%$ & Cove Bay (NE) \\
\hline C3 DOL & $<5 \%$ & Cove Bay (NE) \\
\hline C6 DOL & $<5 \%$ & Cove Bay (NE) \\
\hline CB11 DOL & $<5 \%$ & Conset Bay \\
\hline CB12 DOL & 5 & Conset Bay \\
\hline CB13 DOL & 25 & Conset Bay \\
\hline CB14 DOL & 10 & Conset Bay \\
\hline CUL DOL & $<5 \%$ & Culpepper Island \\
\hline AB1 DOL & 30 & Gent's Bay \\
\hline AB2 DOL & 30 & Gent's Bay \\
\hline AB4 DOL & 90 & Gent's Bay \\
\hline AB5 DOL & 50 & Gent's Bay \\
\hline AB9 DOL & & Pico Tent's Bay \\
\hline AB10 DOL & & \\
\hline B1 DOL & $59 f e$ \\
\hline
\end{tabular}

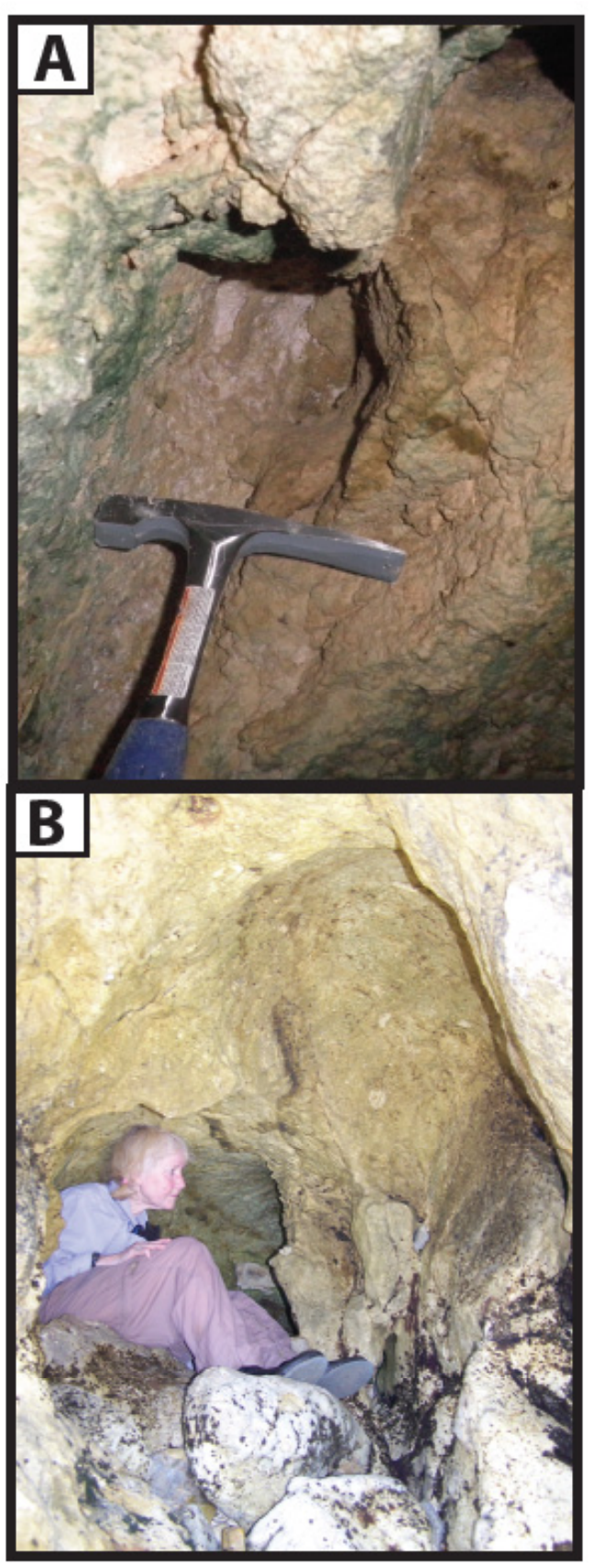

Fig. 5. Cove Bay West caves. A) Dissolutional pockets in the ceiling of largest cave; B) Tubular, blind passage pinching out with cuspate morphology along the right side of the photograph.

\section{DISCUSSION}

\section{Dolomitized chalk}

The range of $\delta^{13} \mathrm{C}$ values (Fig. 7 and Table 2) of dolomite from Barbados can be attributed to three genetic mechanisms:

1) Microbial methane from the Barbados mud volcano field ranges in $\delta^{13} \mathrm{C}$ from about -60 to $-65 \%$ $\mathrm{PDB}$, with one exceptional sample as low as $-113 \%$ PDB (Martin et al., 1996);

2) Thermogenic methane with typical values of $\delta^{13} \mathrm{C}$ ranging from -25 to $-40 \%$ PDB (Schoell, 1988);

3) Soil processes whose $\delta^{13} \mathrm{C}$ values tend to range between zero and -12\% PDB (Burns \& Rossinsky, 1989).

Martin et al.'s (1996) data suggest input of carbon from oxidation of microbial methane, whereas $\delta^{13} \mathrm{C}$ from Barbados dolomite is as low as $-23 \%$ PDB. It is likely that the isotopic range of Barbados dolomite is 


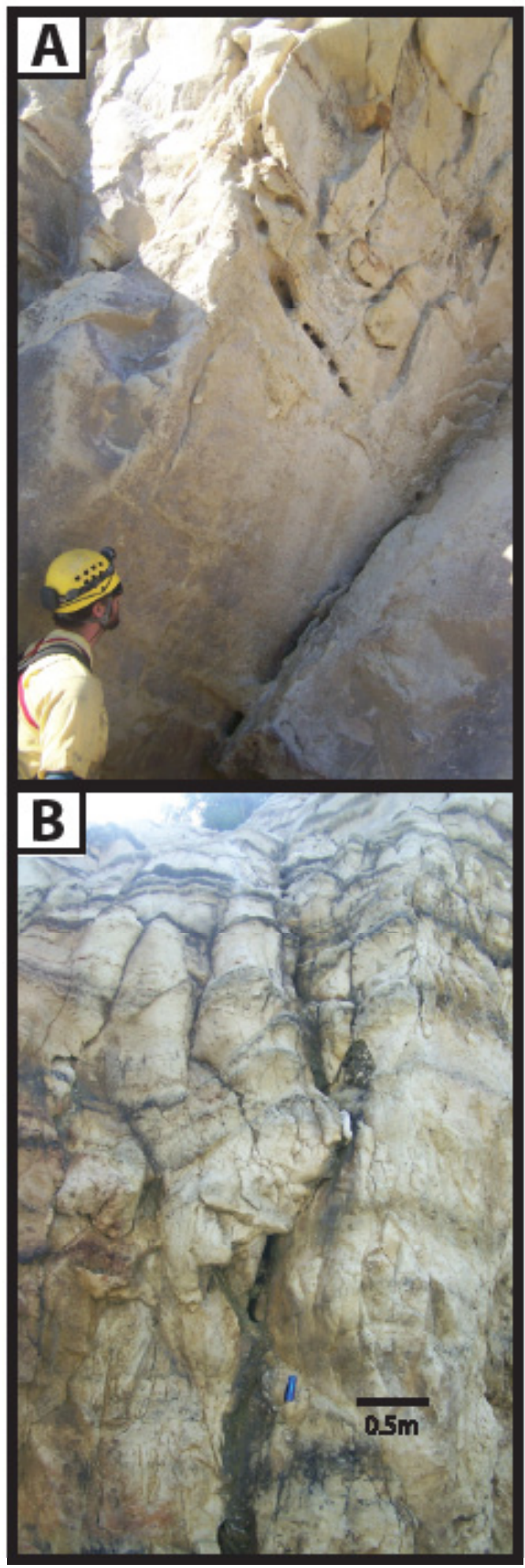

Fig. 6. Small oblong voids developed along fractures at Cove Bay (A) and Gent's Bay (B).

related to thermogenic methane. Variable water-rock ratios and proportions of mixing between the ambient marine pore water and the expelled hypogene fluids best explain the spread in calcite $\delta^{13} \mathrm{C}$ and $\delta^{18} \mathrm{O}$ values. The few highly positive calcite $\delta^{13} \mathrm{C}$ values $(+4.0$ to $+7.3 \%$ o PDB) are interpreted as being derived from $\mathrm{CO}_{2}$ in equilibrium with methane (Hudson, 1977). A complete diagenetic and petrographic history of the dolomitization, including the dolomitized chalks has been addressed (Machel et al., 2011).

In thin sections, samples of chalk are typical carbonate mudstones with abundant microfossils

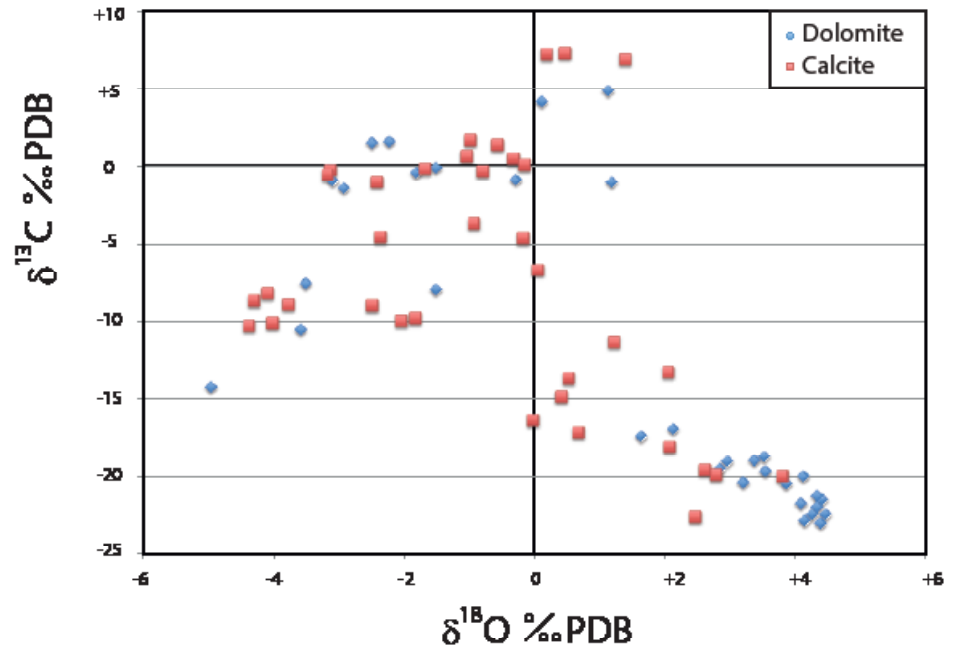

Fig. 7. Oxygen-Carbon isotope plot of all data from this study. See text for further explanation.

(Fig. 4A). Dolomitized chalks are dolomustones with sparse but recognizable microfossils (Fig. 4B). In addition, narrow fractures are present, and these fractures are commonly lined with microsparitic dolomite cemnent (Fig. 4B).

\section{Chalk karstification}

Karstification of the chalks on Barbados follows a three-stage genetic mechanism. The first stage of karstification is the initial dissolution from upward rising fluids along fractures. This accounts for caves and other voids that are associated with fractures (Figs. 3, 5, and 9). These rising fluids likely are hydrocarbon-rich and result in dolomitization. These two phases are possibly syngenetic.

The second stage of karstification is the utilization of the early voids and fractures to host a freshwater lens. A similar utilization of fracture porosity has been documented in telogenetic limestone of New Zealand where flank margin caves developed within fracture networks along a horizontal datum interpreted as a paleosea level (Mylroie et al., 2008). While in the lens margin position, overprinting of the original voids by flank margin mixing zone dissolution occurs, which is considered a "geochemical hypogenic" environment. Also, dolomitization "hardens' the chalk providing structural support of larger void by increasing the apparent shear strength.

The third stage comprises further modification of the void by pseudokarst processes when the void is exposed to littoral conditions by uplift and cliff retreat. The importance of the hardening of the rock and increased shear strength by dolomitization carries over from the previous stage by providing the mechanical support necessary for a large void to exist, which in an undolomitized equivalent would likely not persist.

The unique geologic situation of uplift and rising hydrocarbon-enriched fluids on Barbados allowed chalk dolomitization and initial hypogene dissolution. The dolomitization produced brittle rock behavior in the chalks, creating fracture networks that would be invaded by freshwater that lead to the formation of a particular geochemical environment in which dissolution (mixing corrosion) cause flank margin 


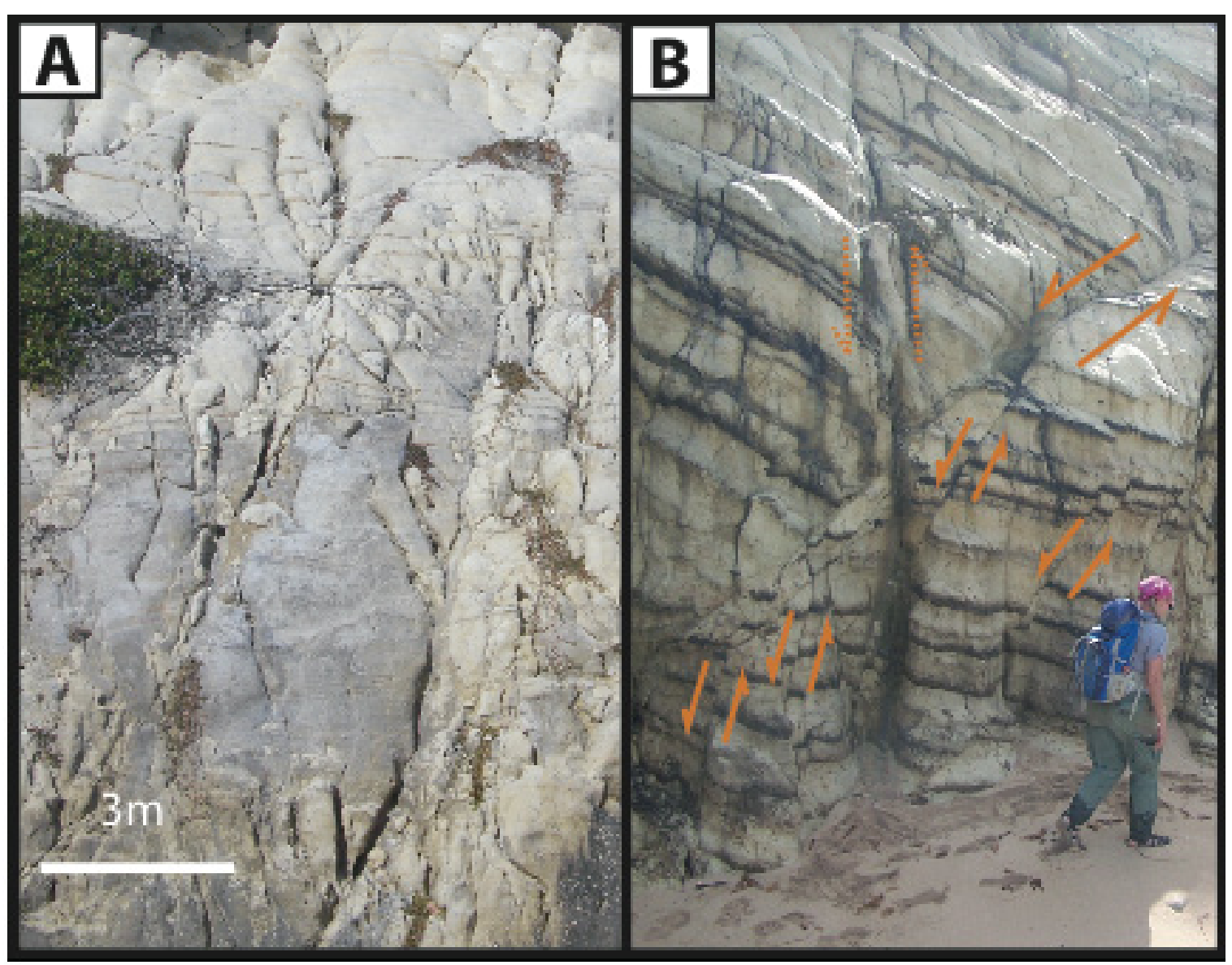

Fig. 8. Fractures and faults in chalk at Cove Bay (A) and Gent's Bay (B). Arrows in Photograph B show displacement.

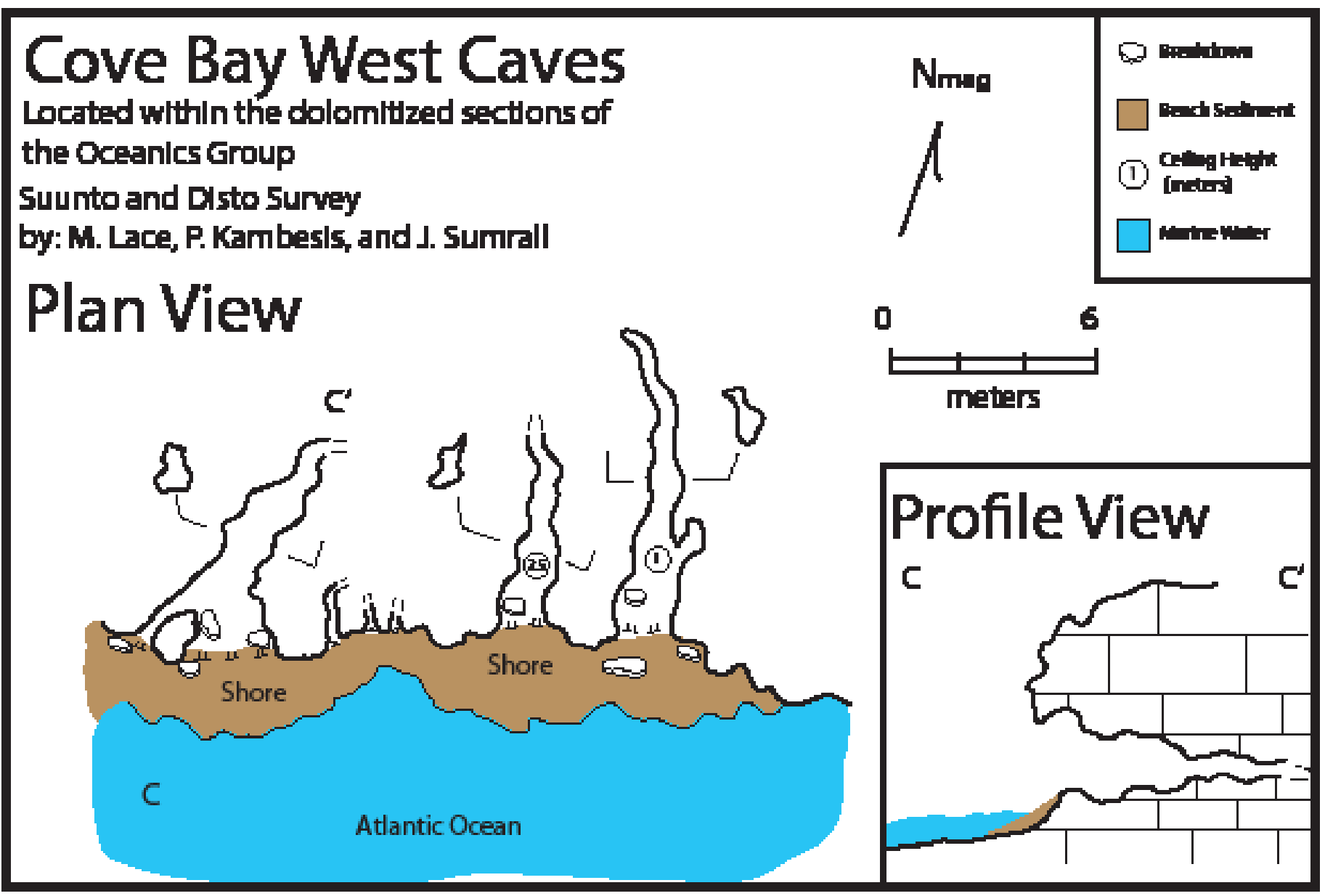

Fig. 9. Cave maps of the dolomitized outcrop at Cove Bay West. These caves occur sporadically along the cliff face just above sea level. 
Table 2. Table of oxygen and carbon stable isotope values from Barbados samples.

\begin{tabular}{|c|c|c|c|c|c|c|}
\hline Sample: & $\delta^{13} \mathrm{C}$ & $\delta^{18} O$ & Sample: & $\delta^{13} \mathrm{C}$ & $\delta^{18} O$ & Location \\
\hline A5 DOL & -19.7 & 3.5 & A5 CAL & -19.9 & 2.8 & Cove Bay(NW) \\
\hline A6 DOL & -19.5 & 2.9 & A6 CAL & -19.6 & 2.6 & Cove Bay(NW) \\
\hline A7 DOL & -20.4 & 3.9 & A7 CAL & -18.1 & 2.1 & Cove Bay(NW) \\
\hline A8B DOL & -20.0 & 4.1 & A8B CAL & -20.0 & 3.8 & Cove Bay(NW) \\
\hline A8C DOL & -22.4 & 4.3 & A8C CAL & -22.6 & 2.5 & Cove Bay(NW) \\
\hline A8D DOL & -18.7 & 3.5 & A8D CAL & -16.3 & 0.0 & Cove Bay(NW) \\
\hline A9 DOL & -19.0 & 3.0 & A9 CAL & -13.6 & 0.5 & Cove Bay(NW) \\
\hline Z1 DOL & -11.9 & 4.7 & Z1 CAL & -2.8 & -0.2 & Cove Bay(NW) \\
\hline Z1A DOL & -12.9 & 3.8 & Z1A CAL & -11.5 & -0.2 & Cove Bay(NW) \\
\hline Z2 DOL & -16.4 & 5.7 & Z2 CAL & -12.0 & 3.9 & Cove Bay(NW) \\
\hline Z7A DOL & -10.2 & 5.4 & Z7A CAL & 0.4 & -0.1 & Cove Bay(NW) \\
\hline Z8A DOL & -2.7 & 0.7 & Z8A CAL & -0.1 & -0.7 & Cove Bay(NW) \\
\hline C1 DOL & 4.1 & 0.1 & C1 CAL & 7.3 & 0.5 & Cove Bay (NE) \\
\hline C10 DOL & -0.9 & -3.1 & C10 CAL & -0.2 & -3.1 & Cove Bay (NE) \\
\hline C11 DOL & -0.9 & -0.3 & C11 CAL & -1.0 & -2.4 & Cove Bay (NE) \\
\hline C12 DOL & -0.4 & -1.8 & C12 CAL & -0.1 & -1.7 & Cove Bay (NE) \\
\hline C13 DOL & -1.4 & -2.9 & C13 CAL & -0.5 & -3.2 & Cove Bay (NE) \\
\hline C2 DOL & -1.0 & 1.2 & C2 CAL & -3.7 & -0.9 & Cove Bay (NE) \\
\hline C3 DOL & -18.9 & 3.4 & C3 CAL & -14.8 & 0.4 & Cove Bay (NE) \\
\hline C6 DOL & -16.9 & 2.1 & C6 CAL & -17.1 & 0.7 & Cove Bay (NE) \\
\hline CB11 DOL & 4.9 & 1.1 & CB11 CAL & 1.4 & -0.6 & Conset Bay \\
\hline CB12 DOL & 1.6 & -2.2 & CB12 CAL & -8.2 & -4.1 & Conset Bay \\
\hline CB13 DOL & -14.2 & -4.9 & CB13 CAL & -8.9 & -3.8 & Conset Bay \\
\hline CB14 DOL & 1.5 & -2.5 & CB14 CAL & 1.7 & -1.0 & Conset Bay \\
\hline CUL DOL & -7.5 & -3.5 & CUL CAL & -8.7 & -4.3 & Culpepper Island \\
\hline AB1 DOL & -21.4 & 4.4 & AB1 CAL & -13.3 & 2.1 & Gent's Bay \\
\hline AB2 DOL & -23.0 & 4.4 & AB2 CAL & -4.6 & -0.2 & Gent's Bay \\
\hline AB4 DOL & -21.2 & 4.3 & AB4 CAL & -6.7 & 0.1 & Gent's Bay \\
\hline AB5 DOL & -22.8 & 4.2 & AB5 CAL & -11.3 & 1.2 & Gent's Bay \\
\hline AB9 DOL & -17.3 & 1.7 & AB9 CAL & -10.1 & -4.0 & Gent's Bay \\
\hline AB10 DOL & -21.7 & 4.1 & AB10 CAL & -9.8 & -1.8 & Gent's Bay \\
\hline B1 DOL & 0.0 & -1.5 & B1 CAL & 0.7 & -1.0 & Pico Teneriffe \\
\hline
\end{tabular}

caves to develop. The coastal position required for flank margin cave development predisposed the caves to littoral overprinting. This unique situation allows for three sequential speleogenetic mechanisms to be documented in a single outcrop.

\section{CONCLUSIONS}

The data presented in this study show the first documented dissolutional caves in chalks and marls modified by dolomitization. These data also show that hypogene processes likely drove dolomitization and initial void formation. The general sequence of events is syngenetic formation of initial hypogene voids and replacement of calcite by dolomite along fractures. Once dolomitized, the rock behaved in a brittle fashion and fracture networks enhanced the flow of hypogene fluids.

A second generation mixing zone dissolution occurred once dolomitized chalks were subaerially exposed, which is required for the formation of a freshwater lens within the chalks. The dolomitized fracture networks hosted a freshwater lens completely within the fracture porosity, so that the low matrix permeability of the chalks was not a hydraulic limitation. This produced additional hypogene dissolutional features, such as flank margin caves along a horizontal datum. Littoral processes led to cliff retreat and exposure of caves, which may overprint the original dissolution features. When overprinting is extensive, the original genetic features are lost and caves are interpreted as littoral.

Barbados thus provides an unusual case of polygenetic void and cave development within dolomitized chalks, driven by a succession and interplay of tectonic uplift, fracturing, hypogene fluid injection, overprinting by mixing zone diagenesis, and eventually mechanical and biological erosion in the current littoral zone. The significance of the voids and caves within the chalks on Barbados is two-fold: 1) these appear to be the first caves documented in dolomitized chalk, and 2) these features show a polygenetic origin documenting that diagenetic changes in lithology allowed the development and preservation of these caves. These results have implications for the behavior of chalks as aquifer or hydrocarbon reservoirs, which would otherwise be difficult to predict.

\section{ACKNOWLEDGEMENTS}

We would like to thank our field team (Patricia Kambesis, Mike Lace, Jeanne Sumrall, Athena Nagel, 
and Joan Mylroie) for all of their hard work mapping, photographing, and helping us to collect data for this particular study, which is part of a larger joint project on island karstification. Financial support was provided through a Discovery Grant to HGM by the Natural Sciences and Engineering Research Council of Canada (NSERC), and by Mississippi State University.

\section{REFERENCES}

Bradshaw J., Caiger N., Halpin M., Le Gear R., Pearce A., Pearman H., Reeve T. \& Sowan P., 1991 - Kent and East Sussex underground. Kent Underground Research Group. Meresborough Books, 128 p.

Burns S.J. \& Rossinsky V., 1989 - Late Pleistocene mixing zone dolomitization, southeastern Barbados, West Indies. Sedimentology, 36: 1135-1137. http://dx.doi.org/10.1111/j.1365-3091.1989.tb01547.x

Day M., 1983 - Doline morphology and development in Barbados. Annals of the Association of American Geographers, 73: 206-219.

http://dx.doi.org/10.1111/j.1467-8306.1983.tb01408.x

Ford D.C., 2006 - Karst geomorphology, caves and cave deposits: a review of North American contributions during the past half century. In: Harmon R.S. \& Wicks C.W. (Eds.), Perspectives on karst geomorphology, hydrology and geochemistry. Boulder, Geological Society of America Special Paper, 404: 1-14.

Hudson J.D., 1977 - Stable isotopes and limestone lithification. Journal of the Geological Society of London, 133: 637-660. http://dx.doi.org/10.1144/gsigs.133.6.0637

Humphrey J.D., 1997 - Geology and hydrogeology of Barbados. In: Vacher H. L. \& Quinn T. M. (Eds.), Geology and hydrogeology of carbonate islands. Developments in Sedimentology, 54, Elsevier, Amsterdam, 381-406.

Joergensen N.O., 1983 - Dolomitization in chalk from the North Sea Central Graben. Journal of Sedimentary Research, 53: 557-564.

Jones I.C. \& Banner J. L., 2003 - Estimating recharge thresholds in tropical karst island aquifers: Barbados, Puerto Rico and Guam. Journal of Hydrology, 278: 131-143. http://dx.doi.org/10.1016/S0022-1694(03)00138-0

Jukes-Browne, A.J. \& Harrison, J.B., 1891 - Geology of Barbados: Part I - The coral rocks of Barbados and other West Indian islands. Quarterly Journal of the Geological Society of London, 47: 197-243. http://dx.doi.org/10.1144/GSL.JGS.1891.047.01-04.17

Klimchouk A.B., 2007 - Hypogene speleogenesis: hydrogeological and morphogenetic perspective. Special Paper no. 1, National Cave and Karst Research Institute, Carlsbad, NM, 106 p.

Klimchouk A.B., 2013 - Hypogene Speleogenesis. In: Frumkin A. (Ed.), Treatise on geomorphology. Vol. 6: Karst geomorphology, Elsevier: 220-240.

Machel H.G., 1999 - Geology of Barbados: a brief account of the island's origin and its major geological features. Barbados Museum and Historical Society, The Garrison, St. Michael, Barbados, 52 p.

Machel H.G., 2011 - The geology of Barbados - a little paradise in its own right. In: Carrington C.M.S. (Ed.), Preserving paradise. Barbados Museum and Historical Society: 13-51.

Machel H.G., Kambesis P.N., Lace M.J., Mylroie J. R., Mylroie J. E. \& Sumrall J. B., 2012 - Overview of cave development on Barbados. In: Kindler P. \& Gamble D. W. (Eds.), Proceedings of the $15^{\text {th }}$ Symposium on the Geology of the Bahamas and Other Carbonate Regions: 96-106.
Machel H.G., Sumrall J.B., Kambesis P.N., Mylroie J.R., Mylroie J.E. \& Lace M.J., 2011, Episodic dolomitization by methane-bearing seawater in Barbados, West Indies. In: 14 ${ }^{\text {th }}$ Bathurst meeting of carbonate sedimentologists, University of Bristol. Abstract Book, p 39, 12-14 July 2011.

Martin J.B., Kastner M., Henry P., LePichon X. \& Lallement S., 1996 - Chemical and isotopic evidence for sources of fluids in a mud volcano field seaward of the Barbados accretionary wedge. Journal of Geophysical Research, 101: 20325-20345.

http://dx.doi.org/10.1029/96JB00140

Maurice L.D., Atkinson T.C., Barker J.A., Bloomfield J.P., Farrant A.R. \& Williams A.T., 2006 - Karstic behavior of groundwater in the English chalk. Journal of Hydrology, 330: 63-70.

http://dx.doi.org/10.1016/j.jhydrol.2006.04.012

McCrea J.M., 1950 - On the isotopic chemistry of carbonates and a paleothermometer scale. Journal of Chemical Physics, 5: 48-51.

Mylroie J.R. \& Mylroie J.E., 2007 - Development of the Carbonate Island Karst Model. Journal of Cave and Karst Studies, 69 (1): 59-57.

Mylroie J. E., Mylroie J. R. \& Nelson C. N., 2008 - Flank margin cave development in telogenetic limestones of New Zealand. Acta Carsologica, 37 (1): 15-40.

Palmer A.N., 2000 - Hydrogeologic control of cave patterns. In: Klimchouk A.B., Ford D.C., Palmer A.N. \& Dreybrodt W. (Eds.), Speleogenesis: evolution of karst aquifers. Huntsville, National Speleological Society: 77- 90.

Palmer A.N., 2007 - Cave geology. Cave Books, Dayton, Ohio, USA, $454 \mathrm{p}$.

Parnell J., Ansong G. \& Veale C., 1994 - Petrology of the bitumen (manjak) deposits of Barbados: hydrocarbon migration in an accretionary prism. Marine and Petroleum Geology, 11: 743-755.

http://dx.doi.org/10.1016/0264-8172(94)90027-2

Rodet J., 1985 - Le développement du karst dans la craie de Normandie et ses conséquences sur la protection des eaux souterraines. Annales de la Société Géologique de Belgique, 108: 33-41.

Scharma T. \& Clayton R.N., 1965 - Measurement of $\mathrm{O}^{18}$ / $\mathrm{O}^{16}$ ratios of total oxygen of carbonates. Geochimica et Cosmochimica Acta, 29: 1347-1353.

http://dx.doi.org/10.1016/0016-7037(65)90011-6

Schellmann G. \& Radtke U., 2004 - A revised morpho- and chronostratigraphy of the Late and Middle Pleistocene coral reef terraces on Southern Barbados (West Indies). Earth Science Reviews, 64: 157-187. http://dx.doi.org/10.1016/S0012-8252(03)00043-6

Schoell M., 1988 - Multiple origins of methane in the Earth. Chemical Geology, 71: 1-10. http://dx.doi.org/10.1016/0009-2541(88)90101-5

Schombourgh R.H., 1848 - The history of Barbados. Longman, Brown, Green and Longmans, $722 \mathrm{p}$. http://archive.org/details/historybarbados00schogoog

Senn A, 1944 - Inventory of the Barbados rocks and their possible utilization. Department of Science and Agriculture Bulletin, 1: 1-40.

Senn A., 1946 - Geological investigations of the groundwater resources of Barbados, B.W.I.: Report of the British Union Oil Company Ltd., 123 p.

Speed R.C., 1983 - Structure of the accretionary complex of Barbados, I: Chalky Mount. Geological Society of America Bulletin, 94: 92-116. http://dx.doi.org/10.1130/00167606(1983)94<92:SOTACO >2.0.CO;2

Speed R.C., 1990 - Volume loss and defluidization history of Barbados. Journal of Geophysical Research, 95: 89838996. http://dx.doi.org/10.1029/JB095iB06p08983 
Speed R.C., 2002 - Field guide to the sub-Quaternary of Barbados. Field Guides, $16^{\text {th }}$ Caribbean Geological Conference, Barbados, June 16-21: 1-83.

Taylor F.W. \& Mann P., 1991 - Late Quaternary folding of coral reef terraces, Barbados. Geology, 19: 103-106. http://dx.doi.org/10.1130/0091-

7613(1991)019<0103:LQFOCR>2.3.CO;2

Thiry M., Franck H. \& Pierre C. 2003 - Chalk dolomitization beneath localized Tertiary depressions in a marginal marine setting in the Paris Basin (France). Journal of Sedimentary Research, 73: 157-170.

http://dx.doi.org/10.1306/091702730157
Torrini R. Jr., Speed R.C. \& Mattioli G.S., 1985 - Tectonic relationships between forearc-basin strata and the accretionary complex at Bath, Barbados. Geological Society of America Bulletin, 96: 861-874.

http://dx.doi.org/10.1130/00167606(1985)96<861:TRBFSA $>2.0 . \mathrm{CO} ; 2$

Wolfe M.J., 1970 - Dolomitization and dedolomitization in the Senonian chalk of Northern Ireland. Geological Magazine, 107: 39-49.

http://dx.doi.org/10.1017/S0016756800054686

Waltham A.C., 1975 - Chalk caves in France. British Cave Research Association Bulletin, 7: 10. 